\title{
Om deltakelse i terrororganisasjon
}

\author{
- Refleksjoner over straffeloven $\S 136$ a og HR-2018-1650-A
}

Av Markus Jerk $\varnothing$

Sammendrag: Artikkelen knytter kritiske kommentarer til straffeloven § 136 a og HR-2018-1650-A, og særlig til forståelsen av vilkåret om deltakelse i en terrororganisasjon samt spørsmålet om brudd på flere av straffebestemmelsens alternativer, deltakelse og rekruttering mv., skal anses som én eller flere overtredelser i relasjon til straffeloven $\S 79$ a, slik at strafferammen forh øyes til det dobbelte.

Nøkkelord: deltakelse, konkurrens, strafferett, terrorisme, ytringsfrihet

Markus Jerk $\varnothing$ er førsteamanuensis ved Institutt for privatrett, Det juridiske fakultet, Universitetet i Oslo.

\section{Introduksjon}

Straffeloven $\S 136$ a viderefører strl. $1902 \S 147$ d, som ble innført ved en lovendring i 2013. Den har overskriften "Straff for deltakelse mv. i en terrororganisasjon», og lyder som følger:

«Med fengsel inntil 6 år straffes den som danner, deltar i, rekrutterer medlemmer eller yter $\varnothing$ konomisk eller annen materiell st $\varnothing$ tte til en terrororganisasjon, når organisasjonen har tatt skritt for å realisere formålet med ulovlige midler.

Medvirkning straffes ikke.»

Bestemmelsen utgjør en rettslig sisteskanse i bekjempelsen av terrorvirksomhet ved at den utfyller de $\varnothing$ vrige straffebudene i lovens kapittel 18 «Terrorhandlinger og terrorrelaterte handlinger», som blant annet er rettet mot terrorhandlinger, terrorforbund, terrortrusler og -finansiering samt oppfordring, rekruttering og opplæring til terrorhandlinger ( $\S \S 131$ til 136).

En foregangssak på dette området var saken i HR-2018-1650-A, hvor en enstemmig Høyesterett uttalte seg om tolkningen av $\S 136$ a og stadfestet tiltaltes straff på ni år i fengsel for deltakelse og rekruttering m.m. til terrororganisasjonen ISIL. Det var første gang det var tatt ut tiltale i Norge for terrorrekruttering, og første gang en tiltalt ble dømt for å være deltaker i ISIL uten å ha vært i land hvor organisasjonen opererer. Det var også første gang Høyesterett skulle ta stilling til flere av de rettslige spørsmålene bestemmelsene om deltakelse mv. gir opphav til. Allikevel har ikke avgjørelsen fått den oppmerksomhet den fortjener. Den oppstiller en presedens som kan få uheldige ringvirkninger, ${ }^{1}$ og som, i mine øyne, er prinsipielt problematisk. Og den tar opp intrikate rettslige problemer som gjør krav på dypere analyser enn de kan bli til del i rettspraksis.

La meg peke på noen av de praktisk viktige og prinsipielle problemer som kan oppstå, og som ikke er mindre viktige om vi ser fremover: En far i Norge utstrekker en økonomisk hjelpende hånd til sin datter i Syria, som har vervet seg til ISIL. Innebærer det at han kan straffes for å ha ytt økonomisk støtte til en terrororganisasjon? En annen nordmann gir religiøse oppmuntringer til en venn som $\emptyset n$ sker å verve seg til ISIL, og bidrar i tillegg med tilrettelegging av reisen og formidling av kontakter $\mathrm{i}$ utlandet. Har han dermed gjort seg skyldig i rekruttering? Lederen av en norsk, radikal muslimsk gruppe har offentlig hyllet terrorhandlinger og hjulpet flere norske fremmedkrigere med å slutte seg til ISIL. Kan vi forestille oss at han gjennom disse handlingene selv har blitt til en deltaker i ISIL?

\footnotetext{
${ }^{1}$ Et aktuelt eksempel er Oslo tingretts dom i TOSL-2020-66298, hvor en kvinne ble dømt til fengsel i 3 år og 6 måneder for deltakelse i terrororganisasjon, etter å ha passet barn og stellet i hjemmet til fremmedkrigere tilsluttet ISIL. Høyesteretts avgjørelse i HR-2018-1650-A var et sentralt premiss i dommen, som er anket.
} 
Straffesanksjoneringen av deltakelse mv. i en terrororganisasjon griper inn i norske borgeres grunnleggende friheter, herunder ytringsfriheten, religionsfriheten og retten til familieliv. Det er viktig å være oppmerksom på noen av de prinsipielle betenkeligheter som kan oppstå når vi går langt i å bekjempe internasjonal terrorisme på hjemmebane. Og det er grunn til å spørre om vi i norsk rett har truffet den rette balansen.

Innenfor rammene av denne artikkelen er det kun rom for å gå inn på enkelte sider av dette problemkomplekset. Jeg vil først gi en kritisk introduksjon til strl. § 136 a i punkt 2. Bestemmelsen har i mine $\varnothing y n e$ fått en uheldig utforming. Deretter presenterer jeg Høyesteretts avgjørelse i punkt 3 , $f ø r$ jeg konfronterer rettens forståelse av to forhold: hva som ligger $i$ alternativet deltakelse i en terrororganisasjon (punkt 4), og om brudd på flere av bestemmelsens alternativer bør anses som én eller flere overtredelser i relasjon til strl. $§ 79$ bokstav a, slik at strafferammen forh $\varnothing$ yes til det dobbelte (punkt 5).

\section{Et innledende, kritisk blikk på straffeloven $§ 136 \mathrm{a}^{2}$}

Lenge var de prinsipielle betenkeligheter ved å kriminalisere deltakelse i en terrororganisasjon ansett avgjørende. ${ }^{3}$ Frem til innføringen av strl. $1902 \S 147 \mathrm{~d}$ var straffansvar kun rettet mot konkrete handlinger som inngikk som ulike ledd i terrorvirksomhet. Dette medførte et potensielt uheldig smutthull i lovgivningen. I et høringsnotat fra juli 2012, som dannet grunnlaget for lovproposisjonen, ${ }^{4}$ viste Justis- og beredskapsdepartementet til uttalelser fra PST og Det nasjonale statsadvokatembetet om at det var

«behov for å kunne straffe personer som er med i gruppen, men har en vagere rolle for eksempel knyttet til generell 'åndelig veiledning', bakmenn som skjuler sine spor osv. Disse vil kunne unngå å delta direkte i de straffbare handlingene, men de er viktige inspiratorer/deltakere og vil kunne utgjøre sentrale ledd i gruppen. Det er videre klart uheldig hvis Norge på dette punkt skal ha et 'hull' i terrorlovgivningen i forhold til de øvrige europeiske land. Det vises her til kriminaliseringsplikten i EUs rammebeslutning. [...] $)^{5}$

Den nevnte rammebeslutningen, som var vedtatt 13. juni $2002,{ }^{6}$ påla medlemsstatene å gjennomføre en rekke tiltak for å forebygge terrorhandlinger. Den er ikke folkerettslig bindende for Norge, men departementet anså i proposisjonen «at det likevel er et mål for Norge å være på linje med EU når det gjelder terrorbekjempelse, blant annet for å sikre effektivt politisamarbeid»». ${ }^{7}$

Rammebeslutningens artikkel $2 \mathrm{nr} .2$ påla medlemsstatene å rette straff mot «ledelse af en terroristgruppe» samt forsettlig

«deltagelse i en terroristgruppes aktiviteter, herunder ved tilvejebringelse af informationer eller materielle midler eller gennem enhver form for finansiering af dens aktiviteter, vel vidende, at denne deltagelse bidrager til terroristgruppens kriminelle aktiviteter».

Den norske bestemmelsen ble ikke utformet med rammebeslutningen som forbilde, men i stedet etter mønster av straffeloven § 129 om «Straff for deltakelse mv. i voldelig sammenslutning med

\footnotetext{
2 Se nærmere om bestemmelsen i Erling Johannes Husabø, Terrorisme i norsk strafferett - Ein analyse av straffelova kapittel 18, Fagbokforlaget, 2018, s. 237-272.

${ }^{3}$ Se Ot.prp. nr. 8 (2007-2008) Om lov om endringer i straffeloven 20. mai 2005 nr. 28 mv. (skjerpende og formildende omstendigheter, folkemord, rikets selvstendighet, terrorhandlinger, ro, orden og sikkerhet, og offentlig myndighet) s. 193-195.

${ }^{4}$ Prop. 131 L (2012-2013) Endringer i straffeloven 1902 og straffeloven 2005 mv. (forberedelse av terror m.m.).

${ }^{5}$ Sitert etter HR-2018-1650-A avsnitt 29.

${ }^{6}$ Council Framework Decision of 13 June 2002 on combating terrorism (2002/475/JHA).

${ }^{7}$ Prop. 131 L (2012-2013) s. 36.
} 
politiske mål». ${ }^{8}$ Denne bestemmelsen, i lovens kapittel 17 «Vern av Norges selvstendighet og andre grunnleggende nasjonale interesser», lyder slik:

«Med fengsel inntil 6 år straffes den som danner, deltar i, rekrutterer medlemmer eller yter $\emptyset$ konomisk eller annen materiell støtte til en sammenslutning som har til formål ved grovt skadeverk, sabotasje, vold eller tvang eller trusler om dette å begå en handling som nevnt i §§ 111-120 eller på annen måte forstyrre samfunnsordenen eller oppnå innflytelse i offentlige anliggender, når sammenslutningen har tatt skritt for å realisere formålet med ulovlige midler.

Medvirkning straffes ikke.»

Valget av denne bestemmelsen som forbilde er neppe heldig.

Én sak er om den nye terrorbestemmelsen isolert sett gir grunnlag for å oppstille bevistemaer som gir et effektivt og rettssikkert bidrag til bekjempelsen av internasjonal terrorisme. Jeg antar at den form for sammenslutning som er nevnt i § 129, og som har til formål å krenke Norges selvstendighet og fred eller å foreta angrep på de høyeste statsorganenes virksomhet mv., jf. §§ 111-120, normalt vil befinne seg på, eller i det minste ha en nær tilknytning til, norsk territorium - og kanskje også vil $\emptyset n$ nke å ha en tydelig tilstedeværelse der - hvilket vil gjøre det enklere i praksis å føre bevis for bevistemaer etter denne bestemmelsen, enn etter $\S 136$ a, som primært er rettet mot internasjonale organisasjoner. Til dette kommer også at ordet «sammenslutning» i § 129 antyder en løsere form for struktur enn ordet «organisasjon» (jf. «terrororganisasjon i § 136 a); det kan være vanskeligere å bevise utover enhver rimelig tvil at en person har deltatt $i$ en organisasjon, enn $i$ en sammenslutning. Det utfordrende ved å føre bevis for at en person er «deltaker i en terrororganisasjon», som i mange tilfeller vil ønske å operere i det skjulte, på fremmed territorium, kan altså gjøre bestemmelsen mindre effektiv enn ønskelig - eller føre til at ordlyden i praksis strekkes for å oppfylle en tydelig politisk målsetning, med redusert rettssikkerhet som konsekvens. ${ }^{9}$

En annen sak er om bestemmelsen, etter en naturlig språklig forståelse, er egnet til å gjennomføre EUs rammebeslutning. Forskjellene er mangfoldige, men den mest betydningsfulle er antagelig at der sistnevnte gir pålegg om å rette straff mot «deltakelse i en terroristgruppes aktiviteter», rammer den norske bestemmelsen den som «deltar $\mathrm{i}$... en terrororganisasjon». Ordet «terrororganisasjon» er ikke nødvendigvis helt sammenfallende med «terroristgruppe», men uavhengig av dette: Et vilkår om å «delta i en terrororganisasjon» favner, etter en naturlig språklig forståelse, ikke det samme som et vilkår om å «delta $i$ en terrororganisasjons aktiviteter». Som jeg kommer tilbake til, kan man delta $i$ en organisasjons aktiviteter uten å være en deltaker i organisasjonen. Vilkåret om deltakelse i en terrororganisasjons aktiviteter er dessuten, rent språklig, mer vidtfavnende enn vilkårene om

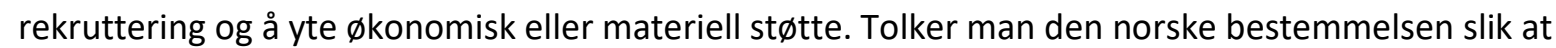
den fullt ut oppfyller rammebeslutningens krav, risikerer man derfor å komme i konflikt med klarhetskravet.

Forarbeidene, som ikke gir mye veiledning til tolkningen av gjerningsbeskrivelsen, etterlater også et inntrykk av at bestemmelsens ordlyd i begrenset grad er tilpasset det man ønsket å regulere med den. I proposisjonen fremgår det at man har ønsket å kriminalisere «kvalifisert deltakelse i terrororganisasjoner», og at dette er «myntet på dem som på ulikt vis bidrar til å danne og opprettholde en terrororganisasjon, for eksempel ved å verve medlemmer, styre eller yte materiell

\footnotetext{
8 Prop. 131 L (2012-2013) s. 41.

${ }^{9}$ Lars Christie gir en moralsk kritikk av deltakerbegrepet i bestemmelsen i «Fredløse fremmedkrigere? Om deltakerbegrepet i den norske straffeloven § 136 a», i Anna Andersson, Sofie A. E. Høgestøl og Anne Christine Lie (red.), Fremmedkrigere - Forebygging, straffeforfølgning og rehabilitering i Skandinavia, Gyldendal juridisk, 2018, s. 83-96.
} 
støtte». ${ }^{10}$ Og i spesialmerknadene til bestemmelsen gjentas det at den kriminaliserer «kvalifiserte former for deltakelse i en terrororganisasjon $"{ }^{11} \mathrm{f} \varnothing \mathrm{r}$ det sies at

«Deltakelse er meget vidtfavnende, og vil blant annet kunne ramme den som anskaffer våpen, datamateriell, kjemikalier eller annet utstyr til å begå en terrorhandling, men uten å være så knyttet til saken at vedkommende kan straffes for medvirkning til den aktuelle terrorhandlingen. Også det å oppfordre til terrorhandlinger og inspirere til aksjoner kan etter omstendighetene omfattes. Rekruttering omfatter typisk vervevirksomhet. Dette må avgrenses mot humanitær st $\varnothing$ tte til sivile i terrorkontrollerte områder, for eksempel leger som jobber på sykehus i slike områder. Dette er imidlertid ikke opplagt i tilfeller der slik virksomhet primært drives i rekrutterings $\varnothing$ yemed. $»^{12}$

Justiskomiteen sluttet seg til forslaget om å kriminalisere «kvalifisert deltakelse i en terrororganisasjon ved ulike former for aktiv støtte», og påpekte videre at

«rekruttering av medlemmer rammes, mens medlemskap faller utenfor. Medvirkning til overtredelse, for eksempel medvirkning til rekruttering, faller også utenfor. Den som deltar, må være kjent med sin deltakelse i organisasjonen, at organisasjonen er en terrororganisasjon, og at den har 'tatt skritt for å realisere formålet med ulovlige midler'. .1 ${ }^{13}$

Samlet sett etterlater disse uttalelsene et inntrykk av at «deltakelse» er meget vidtfavnende i den forstand at den kan bestå i en rekke ulike former for aktiviteter, men samtidig må den være av en kvalifisert art, og rent passiv deltakelse i form av medlemskap i en terrororganisasjon faller utenfor.

\section{Høyesteretts avgjørelse i HR-2018-1650-A}

A hadde vært talsmann for, og var av mange oppfattet som leder av, den sunnimuslimske gruppen Profetens Ummah i Norge. I likhet med ISIL fulgte gruppen den fundamentalistiske retningen salafijihadisme. Den hadde benyttet en voldsorientert retorikk, og flere ganger hyllet terrorhandlinger. ${ }^{14}$

I straffesaken mot ham var han tiltalt for å ha deltatt i terrororganisasjonen ISIL, for å ha rekruttert minst to personer til ISIL, samt for ved fem ulike anledninger å ha gitt $\varnothing$ konomisk eller annen materiell støtte til ISIL, jf. strl. $1902 \S 147$ d og strl. $2005 \S 136$ a.

Slik lagmannsretten oppsummerte sakens faktum, hadde A drevet

«en virksomhet som har bestått i å yte personer forskjellige former for bistand til å reise til Syria/Irak, primært for å være fremmedkrigere for ISIL. Eksponering i media har muliggjort at radikale ekstremister bosatt rundt omkring på $\varnothing$ stlandet har tatt kontakt. Deretter har $A$ i ulik grad støttet opp under allerede eksisterende holdninger til hellig krig og så muliggjort reisen gjennom planlegging, økonomiske bidrag og kontakter ved grensen mellom Tyrkia og Syria. Han har videre sørget for å imøtekomme ønsker fra fremmedkrigere, herunder ivareta deres interesser i Norge, mens disse har oppholdt seg i Syria. ${ }^{15}$

Lagmannsretten fant A skyldig i samtlige tiltaleposter - som også omfattet motarbeidelse av rettsvesenet, trusler og oppbevaring av et elektrosjokkvåpen - og dømte ham til fengsel i 9 år. Hans anke over lovanvendelsen, saksbehandlingen og straffutmålingen ble fremmet for Høyesterett for så

\footnotetext{
${ }^{10}$ Prop. 131 L (2012-2013) s. 41 (min utheving).

11 Prop. 131 L (2012-2013) s. 86.

12 Prop. 131 L (2012-2013) s. 87.

${ }^{13}$ Innst. 442 L (2012-2013) Innstilling fra justiskomiteen om endringer i straffeloven 1902 og straffeloven 2005 mv. (forberedelse av terror m.m.) s. 8 (min utheving).

${ }^{14}$ LB-2017-84014 punkt 3; HR-2018-1650-A avsnitt 25.

15 LB-2017-84014 punkt 5.1; HR-2018-1650-A avsnitt 47.
} 
vidt gjaldt den samlede straffutmålingen samt lovanvendelsen og saksbehandlingen ved vurderingen av overtredelsene av strl. 1902 § 147 d og strl. 2005 § 136 a. Anken ble prøvd på grunnlag av lagmannsrettens beskrivelse av faktum.

Under straffutmålingen vurderte Høyesterett perioden for As deltakelse i ISIL som noe kortere enn lagmannsretten (avsnitt 59 og 102). For $\varnothing v$ rig sluttet førstvoterende seg til lagmannsrettens lovtolkning og konkrete rettsanvendelse. Han fant det «ikke tvilsomt at A har utvist en aktivitet som gjør at han må anses som deltaker i ISIL» (avsnitt 54), og at handlingene «klart [ligger] innenfor det som følger av en naturlig forståelse av uttrykket 'deltar i'», slik at straffebudet på dette punktet er «tilstrekkelig klart, presist og tilgjengelig» (avsnitt 55). Han sa seg også enig i lagmannsrettens vurdering av de to tilfellene av rekruttering til ISIL, samt den $\varnothing$ konomiske og materielle støtten og anså at lovkravet heller ikke her var til hinder for domfellelse (avsnitt 72, 76 og 83). Videre fant han det klart at anken over saksbehandlingen, som gjaldt begrunnelsen for domfellelsen for ett tilfelle av rekruttering, ikke kunne føre frem, da lagmannsrettens domsgrunner var tilstrekkelige (avsnitt 88).

I likhet med lagmannsretten konkluderte også Høyesterett med at As deltakelse, rekruttering og $\varnothing$ konomiske og materielle st $\varnothing$ tte må anses som selvstendige straffbare forhold, slik at strafferammen forhøyes med inntil det dobbelte, jf. strl. 1902 § 61 og strl. $2005 \S 79$ bokstav a (avsnitt 94).

Førstvoterende anså As deltakelse i ISIL som det mest alvorlige forholdet, og antydet en straff på opp mot fem år og seks måneders fengsel for dette forholdet alene (avsnitt 102). Han viste her til lagmannsrettens oppsummering om at $\mathrm{A}$ over en periode på omkring to år har «virket som inspirator, mentor, rådgiver, organisator, fasilitator, mellommann og sendebud for fremmedkrigere i Syria» (avsnitt 101). Også rekrutteringen ble ansett som alvorlige forhold - her var lagmannsrettens utgangspunkt på fengsel i fire år «isolert sett i hvert fall ikke for strengt» (avsnitt 103). Og den $\varnothing$ konomiske og materielle st $\varnothing$ tten - tre $\varnothing$ konomiske bidrag på til sammen snaut 27000 kroner og innkjøp fra to forretninger, hvorav det ene gjaldt «en 50 liters ryggsekk, fire fleecegensere og elleve par hansker» fra XXL (avsnitt 7) - mente han isolert sett ville gitt en noe høyere straff enn det utgangspunkt på ett års fengsel som lagmannsretten hadde lagt til grunn (avsnitt 104). Da påtalemyndigheten ikke hadde påstått høyere straff, var det imidlertid ikke aktuelt å vurdere om fengselsstraffen burde vært lengre, og Høyesterett bekreftet straffen på fengsel i ni år.

I de kommende drøftelser vil jeg ikke problematisere hvorvidt A faktisk var skyldig i anklagene om $\varnothing$ konomisk og materiell st $\varnothing$ tte samt rekruttering til ISIL, selv om også disse sidene av Høyesteretts avgjørelse kan diskuteres. ${ }^{16}$ Drøftelsene er avgrenset til forståelsen av vilkåret om deltakelse i en terrororganisasjon og spørsmålet om deltakelse og rekruttering mv. skal anses som en eller flere overtredelser.

\section{Nærmere om deltakervurderingen}

Det er ikke vanskelig å avgjøre om en person er deltaker i, la oss si, en idrettsforening. Vi kan unders $\varnothing$ ke om vedkommende har fulgt prosedyren for innmelding, om han står oppført i

\footnotetext{
${ }^{16}$ Av lagmannsrettens oppsummering av faktum fremgår det, eksempelvis, at det var As eksponering i media som muliggjorde at fremtidige fremmedkrigere tok kontakt med ham, og han har så støttet opp om deres holdninger og hjulpet dem med å slutte seg til ISIL. Rettene tolker rekrutteringsvilkåret slik at det ikke bare favner «ren vervevirksomhet, men også annen virksomhet som primært drives i rekrutteringsøyemed» (avsnitt 64), og de er samstemte i at loven også må fange opp «den subtile psykologiske overtalelsen som er avgjørende» for tilslutningen (avsnitt 66). Det er imidlertid klart at loven spesifikt peker ut «rekrutterer medlemmer»; den nevner ikke "annen virksomhet som primært drives i rekrutterings øyemed». Så dette reiser, for det første, et semantisk spørsmål om hvor langt vi kan strekke dette vilkårets betydning uten å komme i konflikt med kravet til klar lovhjemmel, jf. Grunnloven § 96 og EMK art. 7 - et spørsmål som Høyesterett i mine øyne tar for lett på. For det andre reiser dette spørsmål om forholdet til ytringsfriheten, som ikke er diskutert i dommen. Hvor reell blir ytringsfriheten hvis ellers lovlige ytringer blir straffbare når noen - gjennom en «subtil psykologisk overtalelse» - tar de til seg eller blir styrket i sin oppfatning om at de plikter å delta i en hellig krig?
} 
medlemsregisteret, og om kontingenten er betalt. Og vi kan anslå omfanget av deltakelsen ved å se på hvilke treninger, kamper og så videre han har meldt seg på og møtt opp til.

$\AA ̊$ avgjøre om en person er deltaker i en terrororganisasjon, kan by på større utfordringer. Som et premiss for diskusjonen vil jeg anta at en terrororganisasjon som ISIL ikke på tilsvarende vis har en formell innmeldingsprosedyre, et tilgjengelig medlemsregister, en kontingent eller noe

medlemsmerke eller annet som kan gi oss et klart svar. Jeg antar at de gjerne er mindre formaliserte og har en «løsere» struktur. At de vil ha deltakere, er allikevel opplagt, men det er også åpenbart at det vil kunne finnes personer som interagerer med organisasjonen uten å være deltakere, og at det gir god mening å si at den kan ha eksterne støttespillere. Spørsmålet er hvordan vi kan trekke opp den rettslige grensen mellom organisasjonens deltakere, etter strl. § $136 \mathrm{a}$, og de som er på organisasjonens utside. Dette var også ett av spørsmålene Høyesterett var stilt overfor i saken mot A. Tiltalte hadde st $\varnothing$ ttet ISIL på ulike måter, men aldri vært i land hvor organisasjonen er aktiv. Hvordan kan vi da avgjøre om han var en deltaker, og ikke bare en støttespiller? Det er om disse spørsmålene jeg i det følgende vil gå i en kritisk dialog med Høyesteretts avgjørelse, før jeg gir mitt syn på hvordan vi bør forholde oss til grensen mellom deltakere og eksterne st $\varnothing$ ttespillere mv.

I Høyesteretts generelle lovtolkning (avsnitt 26-33 og 39-45) gikk førstvoterende gjennom kildene jeg gjennomgikk i punkt 2. Han konkluderte med «at 'deltar i' er et vidt begrep som er ment å omfatte mange ulike former for bidrag til organisasjonens virksomhet», "at det er de aktive bidrag til opprettholdelsen av terrororganisasjonen som rammes», og at en rent passiv tilslutning i form av et «medlemskap» ikke rammes. Videre så han det slik at ikke ethvert aktivt bidrag til organisasjonen kan gi grunnlag for straff. Forarbeidsuttalelsene om at det kreves "kvalifisert deltakelse», tolket han slik «at man må over en terskel». Denne terskelen ligger «ikke ... særlig høyt», men helt bagatellmessige eller perifere bidrag rammes ikke. Han fant ingen holdepunkter for «at medlemskap eller formell tilslutning er et vilkår for å kunne straffes for deltakelse», og straff for deltakelse kunne heller ikke utelukkes der det ikke er mulig å bevise at vedkommende er akseptert som deltaker av organisasjonen (avsnitt 46).

Velvillig lest er det lite å innvende mot dette. Men det er et par ting ved Høyesteretts tolkning det er verdt å merke seg. For det første rettens omtale av tolkningsobjektet som begrepet «deltar $\mathrm{i} »,{ }_{1}^{17} \mathrm{i}$ stedet for den mer fullstendige formuleringen «deltar $i$... en terrororganisasjon». For det andre at retten ikke fors $\varnothing$ ker å utmeisle mer presise vilkår for slik deltakelse. Det er klart at begrepet er vidt, i den forstand at deltakelse kan bestå i mange ulike former for bidrag til organisasjonen, men det forteller oss ikke hvordan vi skal skille mellom deltakere i organisasjonen og eksterne medhjelpere og st $\varnothing t t e s p i l l e r e . ~ H v a$ slags involvering må kreves for å anse noen som deltaker i en terrororganisasjon? Høyesteretts tolkning bidrar i liten grad til å opplyse dette spørsmålet, som er det avgjørende i en sak som denne, hvor det er tatt ut tiltale for deltakelse i ISIL på norsk territorium. Det er først i vurderingen av lagmannsrettens konkrete rettsanvendelse (avsnitt $47 \mathrm{flg}$.) at konturene av førstvoterendes forståelse av dette trer frem - og med disse noen problematiske fasetter.

Førstvoterende åpnet sin konkrete vurdering med å gjengi lagmannsrettens sammenfatning av det den hadde funnet bevist, om at «A [har] drevet en virksomhet som har bestått $\mathrm{i}$ å yte personer forskjellige former for bistand til å reise til Syria/Irak, primært for å være fremmedkrigere for ISIL. [...]» (avsnitt 47; sitert her i punkt 3, over). Etter også å ha gjengitt noen hovedpunkter i denne bistanden (avsnitt 49) samt å ha redegjort for annen praktisk bistand (avsnitt 50) viste han til hvordan "A har spredt propaganda om og støtteerklæringer til ISIL», «vist personlig og oppriktig støtte til ISILs handlinger» og kommet med "offentlige oppfordringer til '(sunni)muslimer om å dra til kalifatet og krige mot de vantro'» (avsnitt 51). Til slutt viste han til lagmannsrettens oppsummering om at A «utvilsomt [har] opptrådt som rådgiver, organisator, fasilitator, mellommann og portåpner, spesielt med sikte på å hjelpe fremmedkrigere frem til ISIL og mens de oppholdt seg i Syria under ISILs

\footnotetext{
${ }^{17}$ Slik også i avsnitt 41 og 55.
} 
kommando» (avsnitt 53), før han konkluderte med at han, etter en totalvurdering av disse forholdene, ikke fant det tvilsomt at $\mathrm{A}$ har utvist en aktivitet som gjør at han må anses som deltaker $\mathrm{i}$ ISIL (avsnitt 54).

Jeg vil se grundigere på enkelte av momentene i denne vurderingen i det følgende, men jeg begynner med sluttsatsen, og lagmannsrettens omtale av A som en «rådgiver, organisator, fasilitator, mellommann og portåpner». Under straffutmålingen skulle A bli påsatt ytterligere hatter; her ble han beskrevet som «inspirator, mentor, rådgiver, organisator, fasilitator, mellommann og sendebud». ${ }^{18}$ Angivelsen av disse flerfoldige rollene er interessant. Man kan spørre hva for eksempel rollen som «mentor» tilfører utover rollene som «inspirator» og «rådgiver»; retorisk inviterer dette spørsmål om ikke the lady doth protest too much. Det mest iøynefallende ved dette er allikevel at lagmannsretten i begge disse oppsummeringene omtaler A som en «mellommann» - mellom fremmedkrigerne og (deltakere i) ISIL, antar jeg ${ }^{19}$ - og at $\mathrm{H} \varnothing$ yesterett gjengir disse helt uten kommentar. Omtalen synes direkte å motsi rettenes konklusjon om at han var deltaker i ISIL. Er man deltaker i en organisasjon, kan man ikke naturlig sies å på samme tid være en mellommann.

I Høyesteretts forståelse synes det imidlertid ikke å eksistere en nødvendig motsetning mellom det å være en mellommann og å være en deltaker i en terrororganisasjon. For det er etter en «totalvurdering» av As aktiviteter at førstvoterende konkluderer med at det ikke er tvilsomt "at A har utvist en aktivitet som gjør at han må anses som deltaker i ISIL» (avsnitt 54); det er "etter en samlet vurdering av alle aktivitetene i hele perioden" at han anser dette bragt på det rene, slik han refererer i avsnitt 58, hvor han viser til «terskelen for å anses som deltakelse». Det rettens konkrete vurdering synes å implisere, er at hvis en persons bidrag til en terrororganisasjon overstiger en viss terskel, så er personen å anse som en deltaker i organisasjonen.

Problemet med en slik forståelse er at den forvitrer skillet mellom deltakere i organisasjonen og

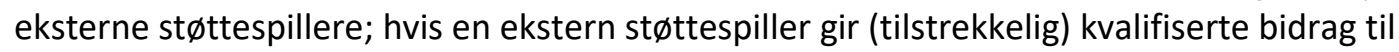
organisasjonen, så anses denne som en deltaker. Det samsvarer ikke med en alminnelig språklig forståelse av hva det er å være en deltaker i en organisasjon. Høyesterett burde heller ha utmeislet selvstendige kriterier for «deltakelse i en terrororganisasjon», og deretter for hva som skal anses som «kvalifiserte bidrag».

Hva innebærer det å være en "deltaker», eller «å delta», i en terrororganisasjon? ${ }^{20}$

\footnotetext{
18 LB-2017-84014 punkt 8; HR-2018-1650-A avsnitt 101.

${ }^{19}$ Han er beskrevet som en mellommann «for [personer som ble] fremmedkrigere i Syria» (avsnitt 101). Den tredje parten i denne relasjonen er ikke spesifisert, og lest isolert er det derfor ikke opplagt at lagmannsretten mente å beskrive ham som en mellommann mellom fremmedkrigerne og (deltakere i) ISIL. Ut fra konteksten er min tolkning imidlertid naturlig. En opplysning om at han skulle være mellommann mellom fremmedkrigere og andre enn (deltakere i) ISIL, ville vært av begrenset relevans - og direkte villedende - i denne sammenhengen, og tolkningen er også nærliggende om vi leser formuleringen i avsnitt 53 i sammenheng med fortsettelsen av avsnittet (og domspremissene for $\varnothing v r i g$ ): «Han har utvilsomt opptrådt som rådgiver, organisator, fasilitator, mellommann og portåpner, spesielt med sikte på å hjelpe fremmedkrigere frem til ISIL og mens de oppholdt seg i Syria under ISILs kommando. Han har i denne forbindelse hatt kontakter i en rekke land, herunder Storbritannia, Danmark, Sverige, Tyrkia og Syria.» En slik tolkning, og den semantiske implikasjonen om at han som mellommann ikke kan ha vært deltaker i ISIL, er uansett så nærliggende at det burde ha påkalt en kommentar fra Høyesterett.

${ }^{20}$ Et parallelt spørsmål kan stilles til den nye bestemmelsen i strl. § 199 som retter straff mot «den som deltar i, rekrutterer medlemmer til eller på annen måte viderefører aktiviteten til en kriminell sammenslutning som er forbudt etter straffeprosessloven $\S 222$ e» (i kraft 1. juli 2021). Kriminaliseringen av slik deltakelse er også prinsipielt betenkelig, og flere av mine påpekninger i denne artikkelen kan rettes tilsvarende overfor utformingen og forståelsen av strl. § 199. Om bakgrunnen for bestemmelsen, se NOU 2020: 4 Straffelovrådets utredning nr. 1 - Kriminalisering av deltakelse i og rekruttering til kriminelle grupper; og Prop. 190 L (20202021) Endringer i straffeprosessloven og straffeloven (kriminalisering av deltakelse i kriminelle sammenslutninger).
} 
Jeg tror ikke det er formålstjenlig, eller mulig, å oppstille et sett av faste, nødvendige og tilstrekkelige vilkår for slik deltakelse. Dette beror på at forskjellige organisasjoner vil kunne ha ulike tilslutningskriterier. Det er for eksempel ulike kriterier som er bestemmende for medlemskap/deltakelse i FN, Greenpeace og Cosa Nostra, og disse tilslutningskriteriene, som kan være eksplisitte eller implisitte, strenge eller inkluderende, osv., er det til en viss grad opp til den enkelte organisasjon å fastsette. Dette innebærer at det også er ulike måter man kan feile i et fors $\varnothing \mathrm{k}$ på å bli deltaker i en organisasjon.

Men jeg vil peke på noen skranker for hva som, etter en naturlig språklig forståelse, kan regnes som slik deltakelse..$^{21}$ For det første vil det at deltakelsen er knyttet til en «organisasjon», medføre at man som deltaker må inngå i en struktur. ${ }^{22}$ Denne trenger ikke være veldig fast, men vi må i det minste forutsette at den har en innside og en utside; det kan ikke være slik at alle organisasjonen kommer $\mathrm{i}$ berøring med, automatisk blir å anse som deltakere. En terrororganisasjon vil for eksempel ha kontakt med sivilbefolkning og motstandere som opplagt ikke er deltakere i organisasjonen.

Det er også klart at en felles overbevisning eller at man kjemper for de samme målene, ikke er tilstrekkelig til at man er deltakere i samme organisasjon. Ulike organisasjoner kan ha overlappende politiske og religiøse idealer og målsetninger, og de kan til og med føre en felles kamp, men likevel slik at det er klart at de forente deltakerne i denne kampen er deltakere i separate organisasjoner.

Det er videre klart at det å delta i en organisasjons aktiviteter, eller å uttrykke støtte til en organisasjon, $i$ seg selv ikke er tilstrekkelig til å konstatere deltakelse i organisasjonen:

Vi kan tenke oss at Greenpeace tar initiativ til demonstrasjoner for å stoppe oljeutvinning i et sårbart område. Utenforstående personer, herunder $\mathrm{K}$, får nyss om det og bestemmer seg for å bli med. Etter den første demonstrasjonen vil K sannferdig kunne bekrefte at han deltok $i$ demonstrasjonen, men like sannferdig kunne benekte at han er en deltaker $i$ Greenpeace. Dette endres ikke alene av den grunn at $K$ hver eneste dag fortsetter å trofast $m \varnothing$ te opp for å demonstrere for klimasaken. Det endres heller ikke om media publiserer bilder av Ks deltakelse og han blir et gjenkjennelig ansikt for saken, slik at andre igjen tar kontakt med ham og han så oppfordrer dem om å støtte opp om Greenpeace og deres sak. Og det blir ikke mindre sant om medlemmer i organisasjonen søker hans kyndige juridiske råd, eller om han donerer penger til organisasjonens kampsak. $\mathrm{K}$ vil fortsatt sannferdig kunne benekte at han er en deltaker i organisasjonen, til tross for at han har deltatt $i$ organisasjonens aktiviteter, at han har støttet den, og at han i fellesskap med mange andre er en deltaker $i$ klimabevegelsen. Om noen skulle utfordre hans forståelse av dette, vil han kanskje presisere at han er en deltaker i Besteforeldrenes Klimaaksjon.

For at K skal bli å anse som en deltaker i organisasjonen Greenpeace, er det klart at han må oppfylle de tilslutningskriterier (kriteriene for deltakelse) som gjelder for denne organisasjonen. På samme måte må vi forutsette at en person for å dømmes for deltakelse i en terrororganisasjon må ha oppfylt tilslutningskriteriene til denne organisasjonen (som, som forutsatt, kan være helt uformelle). ${ }^{23} \mathrm{Hvis}$ ikke er han ikke en deltaker i organisasjonen. ${ }^{24}$

\footnotetext{
${ }^{21}$ Se også Husabø 2018, s. 254-256.

${ }^{22}$ For en nærmere drøfting av kravene til en organisasjons organisering, se ibid., s. 241-242.

${ }^{23}$ «Tilslutningskriterier» bør her leses som reelle tilslutningskriterier; for eksempel bør ikke deltakere i en terrororganisasjon kunne unnskylde seg med at organisasjonen har offisielle tilslutningskriterier som er så strenge at ingen oppfyller dem.

${ }^{24}$ Merk at jeg ikke sier at det må fremlegges eksplisitte bevis for at tilslutningskriteriene har blitt oppfylt; det som må bevises, er bare at tiltalte er deltaker i organisasjonen. Det at en person hver uke deltar i en bokklubb, bør for eksempel gi oss et tilstrekkelig holdepunkt for at personen er deltaker i bokklubben; hvordan vedkommende havnet der, er et sidespor. Min påstand er rent analytisk: For å kunne dømme noen for deltakelse i en terrororganisasjon, må man forutsette at vedkommende på et tidspunkt, eller gjennom et
} 
Et generelt poeng vi kan utlede av disse observasjonene, er at forståelsen av «deltar i» er kontekstavhengig; betydningen av uttrykket vil bero på hva det er forbundet med. Det er en forskjell mellom å være deltaker i en organisasjon og å delta i en organisasjons aktiviteter. Hvorvidt en person er deltaker i en bestemt organisasjon, vil også bero på kjennetegn ved den konkrete organisasjonen. Konkret reiser dette dermed et spørsmål om hva som skal til for å kvalifisere som en deltaker i nettopp ISIL. Dette sentrale spørsmålet drøfter Høyesterett ikke.

Det klart mest alvorlige forholdet det var ført bevis for i saken, er As bistand til og tilrettelegging for fremmedkrigere som dro til Syria/Irak. I sin «totalvurdering» hevder førstvoterende, med henvisning til dette, at A «[p]å denne måten har ... operert aktivt 'på innsiden' av organisasjonen og dermed opptrådt kvalifisert annerledes enn hvis han bare hadde støttet organisasjonen eller dens mål» (avsnitt 54). Men domspremissene godtgjør ikke at han faktisk opererte "på innsiden» av organisasjonen. As bistand og tilrettelegging er klart forenelig med at han var en deltaker i ISIL, men den er like forenelig med at han var en ekstern støttespiller som på ulike måter bidro aktivt til organisasjonen. ${ }^{25}$ Uten kriterier som kan skille mellom disse to alternative hypotesene, er denne påstanden derfor ikke mer enn et postulat. ${ }^{26}$

I tillegg viste førstvoterende til As propaganda og støtteerklæringer og til annen praktisk bistand han hadde ytt til deltakere i ISIL i Syria. Han hadde disponert bankkontoene til enkelte av disse, sendt inn meldekort til NAV for noen av dem, fungert som bindeledd mellom fremmedkrigere og deres familier, og ordnet med juridisk bistand til enkelte av fremmedkrigerne (avsnitt 50 ). ${ }^{27}$ I hvilken grad kan momenter som disse tas til inntekt for at en person er deltaker i en terrororganisasjon?

Det er klart at også deltakere i terrororganisasjoner har en rett til familieliv og til juridisk bistand. Det kan derfor ikke være slik at enhver befatning en person har med deltakere i en terrororganisasjon, gir oss et argument for at personen selv er en deltaker. Med en slik logikk ville personer som gir alminnelig støtte til et familiemedlem som har vervet seg til ISIL (kanskje med sikte på å få vedkommende til å returnere), og på samme måte As forsvarer for norske domstoler, være på vei til å bli deltakere i ISIL, og det kan opplagt ikke være riktig. Høyesterett gjør ikke noe fors $\varnothing \mathrm{k}$ på å oppstille kriterier for hva slags bistand til fremmedkrigere som det er legitimt å legge vekt på i vurderingen av om en person er deltaker i en terrororganisasjon, men det må opplagt skilles mellom relevante og irrelevante former for bistand, og det er ikke opplagt at noen av de nevnte formene for praktisk bistand vil kunne passere en slik test.

Hva vi bør tenke om propagandaen og støtteerklæringene, er mer intrikat. As forsvarer hadde gjort et poeng av at disse ytringene er vernet av ytrings- og religionsfriheten, og at de dermed er straffrie. Til dette bemerket førstvoterende at dersom ytringene om etablering av et kalifat hadde stått alene, kan det nok være at synspunktet hadde ført frem. Men her var de vevd inn i en sammenheng med st $\varnothing$ tte både til ISIL og organisasjonens drap på krigsfanger, og da kunne det ikke være uriktig å trekke de inn i en «samlet vurdering» av om A har deltatt i ISIL (avsnitt 52).

Forsvarerens påminnelse om ytrings- og religionsfriheten er betimelig, men den er nok mer relevant $\mathrm{i}$ forhold til rekrutteringsvilkåret; her treffer den ikke helt. Én måte jeg antar at man kan bli deltaker i en terrororganisasjon på, er om man, under de rette omstendigheter, offentlig sverger troskap til

tidsrom, har blitt deltaker i organisasjonen, og det forutsetter, normalt, noe mer enn at han er en støttespiller, en mellommann, e.l.

${ }^{25}$ Slik Husabø (2018, s. 256-257) påpeker, synes det selvstendige rekrutteringsvilkåret i strl. § 136 a også å

forutsette at rekrutteringshandlinger kan utføres av personer som ikke selv er deltakere i en

terrororganisasjon. Dette er også lagt til grunn i HR-2018-1650-A, se avsnitt 94.

${ }^{26}$ Under straffutmålingen tydde førstvoterende til en sterkere insinuasjon om As deltakelse i ISIL, når han uttalte at den «innebærer ... et klart alvorligere forhold enn det en enkelt fremmedkriger uten ledende rolle gjør seg skyldig i» (avsnitt 101; min utheving). Jeg kommer ikke på et mer passende uttrykk for å beskrive denne uttalelsen i prosessen mot $A$, enn «kafkask».

${ }^{27}$ Se noe mer utførlig i LB-2017-84014 punkt 5.4. 
organisasjonen. Det er i så fall mulig å bli deltaker i en terrororganisasjon ved en ytring. Og et slikt troskapsløfte, vil jeg mene, er vernet av ytringsfriheten; uttalelsen i seg selv er ikke ulovlig. Hvis den kvalifiserer en ytrer som deltaker i organisasjonen, skal han imidlertid straffes - men da for de (kvalifiserte) aktive handlinger han foretar som deltaker i denne, ikke for ytringen. Derfor er det ingen reell konflikt med ytringsfriheten.

Det er allikevel grenser for hva slags ytringer som, etter en naturlig språklig forståelse, kan kvalifisere noen som «deltaker» i en terrororganisasjon. Det kan rettes en tilsvarende innvending mot $\mathrm{H} \varnothing$ yesteretts vektlegging av As ytringer som mot vektleggingen av hans bistand til fremmedkrigere. Problemet med en slik argumentasjonslinje er at slike støtteerklæringer og generelle uttalelser om ISIL og jihad kan fremmes både av deltakere i ISIL og av eksterne sympatisører. Det å simpelthen vise til slike uttalelser i en totalvurdering er derfor ikke egnet til å avgjøre om en tiltalt er en deltaker i ISIL, eller om hen bare er en uttalt (ekstern) sympatis $\varnothing$ r. Det vi i så fall må forutsette, er at ytringene kan utgjøre tungen på vektskålen i en slik totalvurdering - at de, med andre ord, kan utgjøre den siste brikken i puslespillet, som gjør at en ikke-deltaker transformeres til en deltaker.

Kan vi forestille oss at en person i Norge - en person som kan ha ytt støtte til ISIL på ulike måter, men som selv ikke er en deltaker i organisasjonen - ved å uttale at muslimer bør dra til kalifatet og krige mot de vantro, eller at hen st $\varnothing$ tter ISILs krigføring og terrorhandlinger, selv blir til en deltaker i ISIL en organisasjon som opererer i Syria og Irak? Og kan vi forestille oss at personen som sier disse tingene, selv oppnår en bevissthet om at hen nå har blitt til en deltaker i ISIL, gjennom disse ytringene? Jeg har vanskelig for å se hvordan ytringer av en slik art kan ha en slik funksjon. Utfordringen her er ikke forholdet til ytringsfriheten, men at det er en tung argumentativ bevisbyrde som må innfris for å godtgjøre at slike ytringer i det hele tatt er relevante i en vurdering av om en person i Norge forsettlig har deltatt i en utenlandsk terrororganisasjon som ISIL. ${ }^{28}$

En annen mulighet kunne vært å ta ytringene til inntekt for at A var deltaker i ISIL, i en bevisvurdering. Det er klart at slike ytringer er forenelige med at A enten er deltaker i ISIL eller en ekstern, uttalt sympatisør. Vekten at et slikt bevis vil derfor, for det første, bero på fordelingen av deltakere og sympatisører i relevante deler av den norske befolkning. Dette er et empirisk spørsmål, men min antakelse vil være at det er flere sympatisører enn deltakere. For det andre vil beviskraften til et slikt bevis avhenge av hvor trolig det er at personer i disse respektive gruppene offentlig vil uttrykke st $\varnothing$ tte til ISIL: Er det mer sannsynlig for en deltaker i ISIL som befinner seg på norsk territorium, eller for en ekstern sympatisør som antar at han fritt kan fremsette slike ytringer, under vernet av ytringsfriheten? Slike ytringer er, kanskje kontraintuitivt, ikke et godt bevis for at en person er (eller anser seg selv som) deltaker i ISIL, men snarere (gitt visse rimelige forutsetninger) et bevis for det motsatte.

Formelt blir man ikke deltaker i en terrororganisasjon etter en totalvurdering (vil jeg anta). Derfor kan man heller ikke gjennom en totalvurdering av en persons bidrag og vokale støtte til en terrororganisasjon avgjøre om personen selv er deltaker i organisasjonen - i hvert fall ikke på den måten Høyesterett her legger opp til. En slik totalvurdering vil ikke være i stand til å skille mellom deltakere og eksterne støttespillere og uttalte sympatisører. Som påpekt er det også mulig å delta i en organisasjons aktiviteter uten å være en deltaker i organisasjonen, og dette er ikke et subtilt språklig skille, men en distinksjon man vil oppfatte med elementære språklige ferdigheter. Jeg kan derfor ikke si meg enig med førstvoterende når han legger til grunn at lovbestemmelsen, slik Høyesterett har anvendt den, er i samsvar med kravet til klar lovhjemmel. ${ }^{29}$

\footnotetext{
${ }^{28}$ Noe annet vil være å bruke slike ytringer i en vurdering av omfanget av en persons deltakelse. Slike ytringer vil kunne utgjøre en form for propaganda som må regnes som kvalifiserte bidrag til en terrororganisasjon. De vil derfor kunne inkluderes i en vurdering av omfanget av bidragene til en person som er deltaker i organisasjonen. Mitt poeng her er at de vanskelig kan kvalifisere noen som en slik deltaker.

${ }^{29}$ Han uttalte (avsnitt 55): «As handlinger ligger klart innenfor det som følger av en naturlig forståelse av uttrykket 'deltar i' og den kvalifikasjonen som ligger i de forarbeidsuttalelsene jeg har vist til. Straffebudet er på dette punktet tilstrekkelig klart, presist og tilgjengelig.» Uttalelsen overser betydningen av kvalifiseringen om at
} 
Det problematiske ved $\mathrm{H} \varnothing$ yesteretts rettsanvendelse mener jeg blir enda tydeligere om vi ser til vurderingen av starttidspunktet for deltakelsen. Om dette uttalte førstvoterende (avsnitt 58):

«Etter mitt syn kan det ikke være avgjørende at aktiviteten henholdsvis høsten 2013 og sommeren/høsten 2015 var så vidt beskjeden at den etter en isolert bedømmelse neppe ville kommet over terskelen for å anses som deltakelse. Det er på det rene at $A$ etter en samlet vurdering av alle aktivitetene i hele perioden, har vært deltaker i ISIL. Da er det naturlig å sette start- og slutt-tidspunktet til henholdsvis den første og siste aktiviteten som tas i betraktning ved vurderingen.»

Et resonnement som dette kunne kanskje vært forsvarlig om den samlede vurderingen det her siktes til, var et ledd i sakens bevisvurdering; slik kunne man argumentert for at etterfølgende omstendigheter samlet sett gav tilstrekkelig bevis for at A allerede fra et tidligere tidspunkt var deltaker i ISIL. Men her er det klart at den samlede vurderingen inngår i rettsanvendelsen: Det er den samlede aktiviteten som gjør at A, i førstvoterendes vurdering, er å anse som deltaker i ISIL. Allikevel sies det altså her at han allerede fra start-tidspunktet av perioden var å anse som deltaker - det vil si før de hendelser som var avgjørende for å anse han som deltaker, hadde funnet sted, og på grunnlag av disse fremtidige hendelsene. Det må være klart at et slikt grep ikke lar seg forsvare.

Så langt har mine konfrontasjoner med Høyesteretts avgjørelse vært kritiske, og kastet lys over det utfordrende ved å skille deltakere i en terrororganisasjon fra dens eksterne støttespillere, som jeg mener avgjørelsen ikke håndterer på en adekvat måte. Spørsmålet er hvordan vi kan Iøse denne utfordringen: Hvordan kan vi skille mellom organisasjonens deltakere og eksterne støttespillere mv.?

Mitt svar er at det kan vi (i mange tilfeller) ikke.

Når det er relativt enkelt å avgjøre om en person er deltaker i for eksempel en idrettsforening, så henger det sammen med at det finnes en relativt skarp grense mellom foreningens deltakere og utenforstående. Gitt en rimelig presisering av deltaker-begrepet, vil det i de fleste tilfeller være lett å konstatere om kriteriene er oppfylt.

Jeg har antatt at dette forholder seg annerledes for terrororganisasjoner som ISIL, og at disse er mindre formaliserte og har en «løsere» struktur. Hvis det er riktig, innebærer det at det ikke finnes en tilsvarende skarp grense mellom organisasjonens deltakere og utenforstående. Det vil finnes en rekke grensetilfeller hvor det ikke er mulig å avgjøre om en person er deltaker eller ei.

En slik organisasjon vil ha en kjerne av personer som klart er å anse som deltakere, herunder personer med en ledende rolle i organisasjonen og undersåtter som over noe tid har vært tilstrekkelig aktive og er tilstrekkelig integrerte i organisasjonen til at det ikke er tvilsomt at de er deltakere. Utenfor kjernen vil det finnes en vid randsone av personer som interagerer med organisasjonen, eller med dens deltakere, hvor det ikke er klart at de er å anse som deltakere. Dette kan være personer som støtter organisasjonen, som utveksler tjenester med den, eller som samhandler med den på andre måter. Og det kan være personer som har en vennskapelig eller familiær relasjon til organisasjonens deltakere, og som bor og lever side om side med dem - enten det skyldes et personlig valg, eller simpelthen at det er der de har sine liv.

For mange av personene på denne randsonen vil det ikke finnes et objektivt riktig svar på spørsmål om de er deltakere i organisasjonen. For andre kan det finnes et svar. En person kan være en deltaker, og ha oppnådd en bevissthet om dette, men hans atferd vil ikke skille ham ut fra ikkedeltakere med identisk atferd, eller fra personer som ikke er klar over at de har blitt til deltakere. For

deltakelsen må være «i en terrororganisasjon». Straffebudet i seg selv er klart nok; det er domstolenes tolkning og rettsanvendelse som er problematisk. 
utenforstående vil det bare finnes mer eller mindre sterke holdepunkter for at personer på denne randsonen er å anse som deltakere, ikke nok til at dette kan være hevet over enhver rimelig tvil.

Fordi vilkåret «deltar i ... en terrororganisasjon» har en slik vid randsone, hvor deltakere i praksis er uatskillelige (utover enhver rimelig tvil) fra organisasjonens st $\varnothing$ ttespillere mv., må vilkåret presiseres slik at det kun får anvendelse på den harde kjernen av deltakere. Det er ikke mulig å presisere det på en annen måte hvis man skal unngå at bestemmelsen, i strid med dens ordlyd, får anvendelse også på ikke-deltakere. Personer utenfor den harde kjernen av deltakere vil kunne rammes av de andre vilkårene i strl. § $136 \mathrm{a}$, om rekruttering og å yte økonomisk eller materiell støtte. Å rette straff mot videre former for deltakelse i en terrororganisasjons aktiviteter, i tråd med EUs rammebeslutning, må være opp til Stortinget.

\section{5 Én eller flere overtredelser?}

Etter strl. § 79 bokstav a kan fengselsstraffen forhøyes inntil det dobbelte «når en lovbryter ved én eller flere handlinger har begått flere lovbrudd». Dette reiser et generelt spørsmål om hva som skal anses som én eller flere overtredelser av strl. $\S 136$ a i relasjon til bestemmelsen. ${ }^{30}$ Herunder oppstår et mer konkret spørsmål, som var det Høyesterett tok stilling til i HR-2018-1650-A, og som jeg vil fokusere på her: om vi står overfor én eller flere overtredelser der en deltaker i en terrororganisasjon (også) har rekruttert og/eller ytt $\varnothing$ konomisk eller materiell st $\varnothing$ tte til samme organisasjon. ${ }^{31}$

I saker der det uansett ikke er aktuelt å utmåle mer enn 6 års fengselsstraff, bør det være uten betydning om tiltaltes gjerninger anses som én eller flere overtredelser; det avgjørende ved straffutmålingen bør være straffverdigheten til de forhold som anses bevist. Praktisk betydning får spørsmålet i saker hvor det er aktuelt å id ømme strengere straff hvis gjerningene anses som flere overtredelser, slik som i saken i HR-2018-1650-A.

Spørsmålet er ikke diskutert i forarbeidene. Og det er ikke umiddelbart opplagt ut fra lovteksten som kombinerer en kontinuerlig aktivitet (deltakelse) med det som mer naturlig er å anse som konkrete straffbare handlinger (rekruttering og økonomisk og materiell st øtte) - hvilken tilnærming vi bør ta til dette spørsmålet, og om alternativene bør få anvendelse ved siden av hverandre ( $i$ konkurrens), eller om og i så fall når det videre alternativet («deltakelse») bør konsumere de øvrige. Det er om disse spørsmålene jeg i det følgende vil gå i en kritisk dialog med Høyesteretts avgjørelse.

Førstvoterende tok i sin begrunnelse for hvorfor As handlinger burde anses som selvstendige overtredelser, utgangspunkt i Rt. 2005 s. 1524, som han anførte at «gjaldt den tilsvarende problemstillingen ved narkotikalovbrudd etter straffeloven $1902 \S 162 »$ (avsnitt 91). Bestemmelsen rammet den som «ulovlig tilvirker, innfører, utfører, erverver, oppbevarer, sender eller overdrar» narkotika. Om man står overfor ett eller flere brudd på denne bestemmelsen, mente førstvoterende i 2005 at «vil kunne vere vanskeleg å avgjere» (avsnitt 12), men «[t]ruleg må det avgjerast konkret» (avsnitt 13). Uttalelsen hadde fått tilslutning i Rt. 2006 s. 964, hvor det også ble uttalt at det «må bero på en skjønnsmessig helhetsvurdering, som i stor grad må avgjøres ut fra de konkrete forhold i

\footnotetext{
${ }^{30}$ Spørsmål om hva som skal anses som én eller flere overtredelser, oppstår også i andre relasjoner. Se nærmere, Johs. Andenæs, Alminnelig strafferett, 6. utgave ved Georg Fredrik Rieber-Mohn og Knut Erik Sæther, Universitetsforlaget, 2016, s. 369-375; Linda Gröning, Erling Johannes Husabø og Jørn Jacobsen, Frihet, forbrytelse og straff - En systematisk fremstilling av norsk strafferett, 2. utgave, Fagbokforlaget, 2019, s. 573602; Helge Røstad, «Strafferettens lære om konkurrens», Jussens Venner, 1993 s. 1-35, DOI: https://doi.org/10.18261/ISSN1504-3126-1993-01-01; Ørnulf Øyen, «Fortsatt forbrytelse», Jussens Venner, 2005 s. 218-258, DOI: https://doi.org/10.18261/ISSN1504-3126-2005-04-02.

${ }^{31}$ Husabø (2018, s. 264-268) drøfter mer generelt hvilke gjerninger som bør anses som én eller flere overtredelser av bestemmelsen. Han kritiserer lagmannsrettens avgjørelse i samme sak, og trekker konklusjoner som er på linje med mine. Boken kom ut etter at Høyesterett hadde avsagt sin dom. Se også Gröning mfl. 2019, s. 599-600.
} 
den enkelte sak. Sentrale momenter her vil være ulikhet med hensyn til handlingenes art og avstand $\mathrm{i}$ tid og sted for handlingenes utførelse. ${ }^{32}$

Konkret gjaldt de nevnte avgjørelser spørsmål om henholdsvis innførsel og oppbevaring, og oppbevaring og overdragelse, av narkotika kunne anses som ulike overtredelser, hvilket ble besvart bekreftende. Fordi det i mange tilfeller vil være praktisk sett umulig å innføre et parti narkotika, eller å overdra det, uten også å oppbevare det, er det grunn til å møte disse konkrete rettsoppfatningene med en viss reservasjon. ${ }^{33}$ Uansett er det klart at rene tilfeller av det å innføre og oppbevare, eller å overdra og oppbevare, er ulike faktiske handlinger. Høyesteretts vektlegging av «ulikhet med hensyn til handlingenes art og avstand i tid og sted for handlingenes utførelse» underst $\varnothing t t e r$ også at uttalelsene angår spørsmål om når det som intuitivt kan forstås som selvstendige handlinger, skal regnes som selvstendige straffbare overtredelser. Hvis handlingene er tilstrekkelig distinkte, vil bestemmelsens alternativer kunne få anvendelse ved siden av hverandre (i realkonkurrens), på ulike elementer av de straffbare handlingene som anses bevist. Slik jeg ser det, reiser spørsmålet om en deltaker som (også) har rekruttert e.a., skal straffes for flere overtredelser, en annerledes problemstilling, som uttalelsene om narkotikalovbrudd har liten overføringsverdi til.

Vi kan begynne med å se isolert på vilkåret om «deltakelse» i en terrororganisasjon. Det er klart at slik deltakelse er en kontinuerlig aktivitet (slik Høyesterett også uten videre legger til grunn), og at vilkåret rammer aktive, kvalifiserte bidrag til organisasjonen. Vilkåret angir altså en kollektivforbrytelse, og en kontinuerlig overtredelse av det må således regnes som en fortsatt forbrytelse, slik at det skal utmåles en samlet straff på fengsel inntil 6 år for overtredelsen uansett hvor langvarig den har vært. ${ }^{34}$

Vi kan så gå videre og se på de andre vilkårene og deres sammenheng med deltaker-alternativet. Rekruttering av andre deltakere må opplagt anses som et aktivt, kvalifisert bidrag. Og det samme må

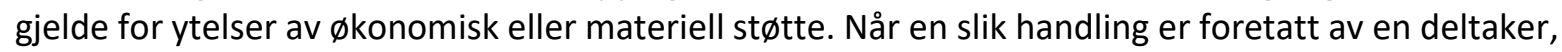
rammes den altså både av deltakervilkåret og av det relevante spesifikke vilkåret. Mens straffebudet om narkotikalovbrudd inneholdt delvis overlappende alternativer («innfører» og «oppbevarer», mv.), står vi altså her overfor spesifikke alternativer hvis overtredelse fullt ut vil være inneholdt i det videre alternativet der handlingene er utført av en deltaker.

Det er klart at det ikke kan utmåles straff to ganger for, for eksempel, en rekrutteringshandling foretatt av en deltaker; et viktig prinsipp i strafferetten er at man ikke skal straffes flere ganger for samme forhold..$^{35}$ Vilkårene om rekruttering og deltakelse kan derfor ikke anvendes ved siden av hverandre, i realkonkurrens, på slike handlinger.

Fordi deltaker-alternativet kun favner aktive bidrag (mens medlemskap faller utenfor) er det også klart at de to vilkårene ikke rammer ulike sider av rekrutteringshandlinger; en slik handling blir ikke i seg selv mer straffverdig om den er utført av en deltaker i en terrororganisasjon. De kan derfor heller ikke anvendes ved siden av hverandre i idealkonkurrens.

Når slike handlinger altså rammes av begge vilkårene, på identisk vis, må det etter mitt syn være riktig å la den videre kategorien («deltakelse») konsumere den snevrere («rekruttering») når vi står overfor rekrutteringshandlinger foretatt av en deltaker, slik at det kun utmåles straff for overtredelse av vilkåret om deltakelse, og strafferammen ikke fordobles. Å utmåle straff for disse handlingene både etter rekrutterings- og deltakervilkåret ville være i strid med prinsippet om dobbeltstraff.

Høyesterett har ikke utmålt straff for det samme forholdet to ganger. Det Høyesterett gjør, for å få handlingene til å harmonere med rettens innfallsvinkel om at de er å anse som ulike overtredelser, er

\footnotetext{
${ }^{32}$ Rt. 2006 s. 964 avsnitt 15; HR-2018-1650-A avsnitt 92.

${ }^{33}$ I denne retning også Husabø 2018, s. 266-267. Sml. Gröning mfl. 2019, s. 598-599.

${ }^{34}$ Se f.eks. Røstad 1993, s. 3-4; Ørnulf Øyen 2005, s. 218-220.

${ }^{35}$ Se f.eks. Gröning mfl. 2019, s. 581-583.
} 
å separere rekrutteringshandlingene og den $\varnothing$ konomiske og materielle st $\varnothing t t e n$ fra deltakelsen for

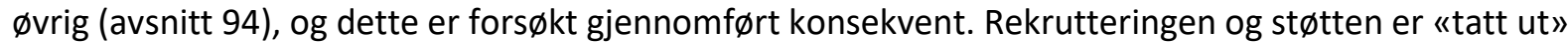
av deltakelsen, slik at vi står igjen med tilsynelatende separate overtredelser.

En slik separasjon reiser enkelte prinsipielle betenkeligheter.

Jeg er for det første skeptisk til om en slik separasjon er mulig, rent psykologisk, - heri ligger en potensiell, praktisk viktig feilkilde man bør være oppmerksom på: Det er vanskelig å se bort fra at en person (angivelig) har rekruttert til ISIL, ved vurderingen av om hen er en deltaker i ISIL, og ved vurderingen av deltakelsens omfang og klanderverdighet. Ved en slik separasjon vil det derfor være en fare for at de rettsfakta som er relevante under rekrutteringsvilkåret (e.a.), «farger av» på vurderingen av om personen har deltatt i organisasjonen. (Ville A vært dømt som deltaker om det ikke var for disse handlingene?)

Det reiser videre et spørsmål om hva man står igjen med, når man som her tar ut de konkrete straffbare handlinger som anses bevist, fra selve deltakelsen. I dette tilfellet synes svaret å være As bistand til andre fremmedkrigere som sluttet seg til ISIL (personer som han ikke hadde rekruttert), hans hjelp med å opprettholde kontakt mellom fremmedkrigere og deres familier og å skaffe juridisk bistand mv., samt hans offentlige ytringer. Som påpekt over er ytringene og ( $i$ hvert fall deler av) den praktiske bistanden i utgangspunktet lovlige handlinger. Og her må vi også minnes at medvirkning til deltakelse ikke er straffbart, jf. § 136 a annet ledd. Så det paradoksale her er at denne «deltakelsen» - som var ansett som «det alvorligste forholdet» (avsnitt 100), og som alene var ansett å forsvare en straff på opp mot fem år og seks måneders fengsel (avsnitt 102) - er spunnet av handlinger som (i hvert fall hovedsakelig, og som det klare utgangspunkt) i seg selv er straffrie.

Generelt er den prinsipielle betenkeligheten ved en slik separasjon at man risikerer enten å utmåle straff flere ganger for samme forhold - bevisst eller ubevisst - eller å idømme straff for forhold som i seg selv er lovlige, eller for forhold som det ikke er ført tilstrekkelig bevis for. Her må man derfor vokte seg vel, om man skal gå klar av skrankene etter retten til en rettferdig rettergang, lovkravet og uskyldspresumsjonen.

Uavhengig av disse prinsipielle betenkelighetene, mener jeg noen enkle refleksjoner over bestemmelsen og dens utforming støtter opp under at deltakelse og rekruttering ( $\mathrm{mv}$.) til samme organisasjon ikke bør anses som flere overtredelser, og, mer generelt, at strafferammen ikke bør forhøyes til det dobbelte ved brudd på flere av bestemmelsens alternativer.

Vi kan først merke oss at det er visse sammenhenger mellom bestemmelsens vilkår, «danner, deltar $\mathrm{i}$, rekrutterer medlemmer eller yter $\varnothing$ konomisk eller annen materiell st $\varnothing$ tte til en terrororganisasjon». En person som er med på å danne en terrororganisasjon, vil normalt også bli en deltaker i organisasjonen - og vil kanskje også ipso facto være å anse som en deltaker i denne. Og det er klart at en som danner eller deltar i en terrororganisasjon, både kan rekruttere andre deltakere og selv yte

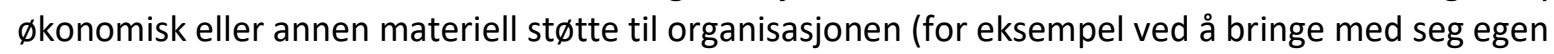
bekledning og utstyr ved tilslutningen). I mange tilfeller vil en stifter/deltaker derfor kunne ha foretatt handlinger som innebærer et brudd på flere av vilkårene i bestemmelsen.

Vi kan videre se for oss tre ulike tilfeller av deltakelse: deltakelse uten rekruttering (og uten $\emptyset$ konomisk eller annen materiell st $\varnothing$ tte), deltakelse som utelukkende består i rekruttering, og blandede former for deltakelse.

I og med at deltakelse er en kontinuerlig aktivitet, skal deltakelse uten rekruttering (mv.) straffes med fengsel inntil seks år, og straffen skal fastsettes ut fra straffverdigheten til de samlede aktive bidrag til organisasjonen som er funnet bevist. Det samme må gjelde der tiltaltes deltakelse 
utelukkende består i rekrutteringshandlinger. En utmåling av straff både for deltakelse og for rekruttering ville innebære at det ble utmålt straff to ganger for samme forhold. ${ }^{36}$

Hva så med de blandede formene for deltakelse: bør vi behandle disse annerledes - det vil si strengere - enn rene tilfeller av deltakelse/rekruttering? En ulikeartet behandling kunne kanskje forsvares om det å rekruttere, eller å yte økonomisk eller annen materiell st $\varnothing t t e$, var atypiske handlinger for deltakere i en terrororganisasjon, eller om disse var spesielt graverende. Men disse fremstår for meg som nokså alminnelige måter å bidra på for deltakere i terrororganisasjoner. Og det er mange andre former for bidrag vi kan forestille oss - som ledd i planleggingen og utførelsen av terrorhandlinger, eller som ledd i krigføring eller i å underkue og spre frykt blant en sivilbefolkning som virker vel så alvorlige.

Dette reiser et spørsmål om hvorfor akkurat disse konkrete formene for bidrag til en terrororganisasjon er særskilt nevnt i strl. § 136 a. Og det naturlige svaret på det, vil jeg hevde, er at dette er bidrag til en terrororganisasjon som det både er praktisk mulig for ikke-deltakere å yte, og som det er hensiktsmessig å kunne straffe noen for også i tilfeller hvor det ikke finnes bevis for en nærmere tilknytning til organisasjonen. Så poenget med å nevne disse alternativene er at de skal utfylle de foregående ved å fange opp kvalifiserte bidrag fra ikke-deltakere.

Det bestemmelsen er ment å favne, er (det totale omfanget av) alle kvalifiserte, aktive bidrag til en terrororganisasjon. Mens den abstrakte og generelle kategorien «deltar i» vil omfatte alle konkrete former for kvalifiserte bidrag fra deltakere, vil de konkrete alternativene fange opp kvalifiserte, aktive bidrag fra ikke-deltakere. ${ }^{37}$ Selv om vilkårene etter en naturlig språklig forståelse overlapper, er denne overlappingen altså i seg selv ikke et poeng med bestemmelsens formuleringer. De er i stedet ment å være gjensidig utfyllende vilkår.

Vi kan til slutt observere at dersom deltakelse, som en kontinuerlig aktivitet, skal straffes med fengsel inntil seks år, uten hensyn til deltakelsens varighet eller omfang (en person kunne i prinsippet ha vært ISILs $\emptyset$ verste leder i en årrekke uten å få mer enn seks år i fengsel), blir det inkonsekvent om det utmåles lengre straff for en relativt kortvarig deltakelse som også inkluderte rekruttering eller $\varnothing$ konomisk eller annen materiell støtte. Det er heller ikke mer straffverdig om man først, som ikkedeltaker, rekrutterer, og deretter blir deltaker, enn om man i hele tidsrommet har vært en deltaker som blant annet har rekruttert. I et strafferettslig perspektiv ( $i$ kontrast til et straffeprosessuelt) er $i$ det hele tatt lite tjent ved å betrakte ulike bidrag til en terrororganisasjon som selvstendige overtredelser. Det bør utmåles en samlet straff ut fra straffverdigheten til de samlede, kvalifiserte, aktive bidrag til organisasjonen, innenfor en strafferamme på seks år i fengsel. ${ }^{38}$

\footnotetext{
${ }^{36}$ Der tiltalte har rekruttert flere personer, oppstår også et spørsmål om vi står overfor flere straffbare rekrutterings-forhold (i kontrast til én kontinuerlig deltakelse). Mine argumenter under kan anføres også mot en slik forståelse. Slik også Husabø 2018, s. 268.

${ }^{37}$ Andre typer av bidrag er, presumptivt, enten antatt å være av en slik art at de vanskelig kan anses utført av en ikke-deltaker, eller bedømt å ikke være tilstrekkelig straffverdige.

${ }^{38}$ Den nye bestemmelsen i strl. § 199, om straff for deltakelse mv. i en forbudt kriminell sammenslutning, gir opphav til en parallell problemstilling. I NOU 2020: 4 punkt 17.5.2 ble det konstatert at den som er tiltalt for ulike aktive deltakelseshandlinger i samme gruppe, kun skal anses for å ha overtrådt bestemmelsen én gang. I Prop. 190 L (2020-2021) punkt 7.7 fikk denne forståelsen kun tilslutning som et utgangspunkt, med henvisning til Rt. 2006 s. 964 avsnitt 15.
} 